\title{
Psychologically informed engagement with the Matthean pericopes on Pilate and Judas through Jungian lenses: The sensing, intuition, feeling and thinking approach
}

\begin{tabular}{|c|c|}
\hline \multicolumn{2}{|c|}{$\begin{array}{l}\text { Authors: } \\
\text { Leslie J. Francis } 1,3 \text { (I) } \\
\text { Christopher F. Ross }{ }^{2,3}\end{array}$} \\
\hline \multicolumn{2}{|c|}{$\begin{array}{l}\text { Affiliations: } \\
{ }^{1} \text { Warwick Religions and } \\
\text { Education Research Unit, } \\
\text { University of Warwick, } \\
\text { United Kingdom }\end{array}$} \\
\hline \multicolumn{2}{|c|}{$\begin{array}{l}{ }^{2} \text { Wilfrid Laurier University, } \\
\text { Canada }\end{array}$} \\
\hline \multicolumn{2}{|c|}{$\begin{array}{l}{ }^{3} \text { Department of New } \\
\text { Testament Studies, Faculty } \\
\text { of Theology and Religion, } \\
\text { University of Pretoria, } \\
\text { South Africa }\end{array}$} \\
\hline \multicolumn{2}{|c|}{$\begin{array}{l}\text { Research Project Registration: } \\
\text { Project Leader: A.G. van Aarde } \\
\text { Project Number: } 2334682\end{array}$} \\
\hline \multicolumn{2}{|c|}{$\begin{array}{l}\text { Description: } \\
\text { This research is part of t } \\
\text { research project, 'Biblica } \\
\text { Theology and Hermeneu } \\
\text { directed by Prof. Dr And } \\
\text { van Aarde, Post Retirem } \\
\text { Professor and Senior } \\
\text { Research Fellow in the } \\
\text { Dean's Office, Faculty of } \\
\text { Theology and Religion, } \\
\text { University of Pretoria. }\end{array}$} \\
\hline \multicolumn{2}{|c|}{$\begin{array}{l}\text { Corresponding author: } \\
\text { Leslie Francis, } \\
\text { leslie.francis@warwick.ac.uk }\end{array}$} \\
\hline \multicolumn{2}{|c|}{$\begin{array}{l}\text { Dates: } \\
\text { Received: } 11 \text { July } 2018 \\
\text { Accepted: } 04 \text { Sept. } 2018 \\
\text { Published: } 05 \text { Nov. } 2018\end{array}$} \\
\hline \multicolumn{2}{|l|}{ Read online: } \\
\hline 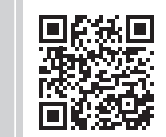 & $\begin{array}{l}\text { Scan this QR } \\
\text { code with your } \\
\text { smart phone or } \\
\text { mobile device } \\
\text { to read online. }\end{array}$ \\
\hline
\end{tabular}

Within the passion narrative Matthew adds important pericopes to the Marcan text concerning both Pilate and Judas. These additional pericopes provide a rich resource for exploring the psychological motivation of and the psychological consequences for these two key actors in the betrayal and crucifixion of Jesus. The present study employs the Jungian framework of the sensing, intuition, feeling and thinking (SIFT) approach to Biblical hermeneutics to explore the interpretation of Matthew 27:19-25 (concerning Pilate) through the lenses of sensing and intuition, and the interpretation of Matthew 27:3-10 (concerning Judas) through the lenses of thinking and feeling among 24 experienced preachers in Ontario, Canada. The findings confirm the hypotheses advanced by the SIFT approach that significant differences emerge between the psychological perceptions of sensing types and intuitive types, and that significant differences emerge between the psychological evaluations of thinking types and feeling types.

\section{Introduction}

Both Pilate and Judas have attracted considerable attention from theological, historical, literary, and psychological perspectives, as exemplified by Bond (1998) and Wroe (1999) on Pilate and by Klassen (1996) and Gubar (2009) on Judas. In an early attempt to uncover 'the psychology of Judas Iscariot', Uraguchi (1918) argued that the:

character of Judas Iscariot presents a problem hard to solve, yet rewarding to diligent effort. Considered by psychological analysis his personality presents a mental condition very similar to the common consciousness of present-day people. (p. 345)

\section{Psychological issues in the passion narrative}

The Marcan passion narrative raises important questions of a psychological nature regarding the principal agents in effecting the arrest, trial, and death of Jesus, particularly concerning Judas (who, according to the tradition, identified and betrayed Jesus under the cloak of darkness) and Pilate (who, according to the tradition, sat in the seat of judgement and held the political authority to release or not to release Jesus to freedom). These questions include both issues of psychological motivation (why did Pilate and Judas act in the way in which they did?) and issues of psychological consequences (in what way, if at all, did these public actions carry personal consequences?).

The redaction critical approach to the problems raised by the Synoptic gospels may construe Matthew as one of the early commentators struggling with the problems raised by the Marcan passion narrative. Seen through psychological lenses, with respect to Pilate and Judas, it seems that Matthew has addressed the psychological questions of motivation and consequences in both creative and imaginative ways. In the case of Pilate, Matthew interpolates two narratives into the Marcan text: the one concerning the intervention of Pilate's wife who warned her husband about the special knowledge she had received in a dream concerning Jesus; and the other concerning the bowl of water and Pilate publicly washing his hands of further and lasting responsibility for implementation of the popular will. In the case of Judas, Matthew interpolates into the Marcan text a complex and detailed narrative regarding Judas returning the 30 pieces of silver, Judas

How to cite this article: Francis, L.J. \& Ross, C.F., 2018, 'Psychologically informed engagement with the Matthean pericopes on Pilate and Judas through Jungian lenses: The sensing, intuition, feeling and thinking approach', HTS Teologiese Studies/Theological Studies 74(1), a5179. https://doi.org/10.4102/hts.v74i1.5179

Copyright: @ 2018. The Authors. Licensee: AOSIS. This work is licensed under the Creative Commons Attribution License. 
being disowned and the blood money being rejected by the chief priests, the purchase of the Potter's field known to this day as the Field of Blood, and Judas' final act of suicide. Here, indeed, in the Matthean passion narrative is a well-stocked resource for psychological investigation.

Some biblical commentators continue to approach the distinctive Matthean additions to the Marcan narratives concerning Judas and Pilate in a variety of ways independent of psychological theory or language. For example, Callon (2006) has provided a rigorous analysis of Matthew's portrayal of Pilate which is rooted in a close scrutiny of the wider Matthean text and of other historical resources. Nonetheless, it remains clear that other biblical commentators on Matthew's Gospel routinely reflect on the psychological issues raised by the Matthean additions to the Marcan narrative. In terms of the intervention made by Pilate's wife, Boring (1994:486) argues that this increases Pilate's guilt, since 'he now knows by divine revelation that Jesus is innocent'. France (2007:1054) argues that 'this unexpected interruption of the trial narrative further explains Pilate's reluctance to convict Jesus'. In terms of Pilate's act of hand washing, Barclay (1957:399) speaks of the 'strange and tragic picture of him washing his hands ... Pilate could not stand against the mob and made the futile gesture of washing his hands'. Brown (1994:637) draws the parallel between this 'haunting ... scene of blood that cannot be easily eradicated' and the guilty conscience of Lady Macbeth. In terms of the guilt expressed by Judas and his suicide, Wright (2002:174) reflects on the big difference between remorse, such as that of Judas, and genuine repentance, such as that of Peter. France (2007:1039) drives that comparison more fully, contrasting Matthew's presentation of Judas' expression of regret (I have sinned) with Peter's bitter weeping. France reflects on how one story ends in despair and suicide, and the other 'in the full rehabilitation of the future leader of the church'.

\section{Psychological perspectives in biblical interpretation}

Psychological perspectives in biblical interpretation embrace a range of different approaches rooted within psychological theories and psychological methods. Reviewing this emerging literature, Village (under review) distinguishes between two main approaches. The first one places the weight on the text itself. This approach characterises contributions to the Psychology and Bible programme unit of the Society of Biblical Literature (see Ellens 2012) and is exemplified through the following family of studies by Rollins (1999), Kille (2001), Ellens and Rollins (2004) and Rollins and Kille (2007). In this approach, psychological constructs are used as the lenses through which particular biblical texts, themes, or characters are viewed and interpreted, in ways similar to those employed by scholars using feminist, liberationist, or ethnic lenses.

The second approach places the weight on the reader and is related both to wider reader-response theory (Bleich 1978; Booth 1984; Fish 1980) and to the reader-perspective approach to biblical hermeneutics as originally shaped by attention on the social location of the reader in terms of factors such as gender and ethnicity (Segovia \& Tolbert 1995a; 1995b). The idea that the reader perspective might be shaped by the psychological type profile of the reader, drawing on psychological type theory as proposed by Jung (1971), was advanced in a couple of early papers by Stiefel (1992) and Bassett, Mathewson and Gailitis (1993) and subsequently developed into the sensing, intuition, feeling and thinking (SIFT) approach to biblical hermeneutics and liturgical preaching in a series of theoretically driven studies by Francis (1997), Francis and Atkins $(2000 ; 2001 ; 2002)$ and Francis and Village (2008). The SIFT approach has also been explored in a sequence of qualitative studies in which 'readers' who share the same psychological type preferences have been invited to work in groups to explore specific passages of scripture. The theory is that such groups (constituted on the basis of psychological type preference) lead to greater clarity and greater distinctiveness of the type-associated readings of text. The following passages of scripture have been explored in this way: the feeding of the 5000 reported in Mark 6:34-44 (Francis 2010); the resurrection narratives reported in Mark 16:1-8 and Matthew 28:1-15 (Francis \& Jones 2011); the cleansing of the Temple and the incident of the fig tree reported in Mark 11:11-21 (Francis 2012a; Francis \& ap Siôn 2016b); the Johannine feeding narrative reported in John 6:4-22 (Francis 2012b); the narrative of separating sheep from goats reported in Matthew 25:31-46 (Francis \& Smith 2012); the birth narratives reported in Matthew 2:13-20 and Luke 2:8-16 (Francis \& Smith 2013); two narratives concerning John the Baptist reported in Mark 1:2-8 and Luke 3:2b-20 (Francis 2013; Francis \& Smith 2014); the Johannine feeding narrative reported in John 6:5-15 (Francis \& Jones 2014); two passages from Mark exploring different aspects of discipleship reported in Mark 6:7-14 and Mark 6:33-41 (Francis \& Jones 2015a); the foot washing account reported in John 13:2b-15 (Francis 2015); two healing narratives reported in Mark 2:1-12 and Mark 10:46-52 (Francis \& Jones 2015b); the narrative of blind Bartimaeus reported in Mark 10:46-52 (Smith \& Francis 2016); the Road to Emmaus narrative reported in Luke 24:13-35 (Francis \& ap Siôn 2016a; Francis \& Smith 2017); the Lucan call of the first disciples reported in Luke 5:1-7 (Francis \& ap Siôn 2017); and the missionary journey reported in Mark 6:6b-16 (Francis, Smith \& FrancisDehqani 2017). More recently this research tradition has also been developed in Poland by Chaim (2013; 2014; 2015).

Psychological type theory, on which the SIFT approach builds, was originally shaped by Jung (1971) and subsequently developed by a series of psychometric instruments that operationalise the theory for empirical studies, including the Keirsey Temperament Sorter (Keirsey \& Bates 1978), the Myers-Briggs Type Indicator (Myers \& McCaulley 1985), and the Francis Psychological Type Scales (Francis 2005). This model distinguishes between two core psychological processes: the perceiving process that is concerned with gathering information and the judging process that is concerned with evaluating information. Jung described perceiving as the irrational process since it was not concerned 
with evaluation, and judging as the rational process since it was concerned with evaluation. The theory suggests that each process is reflected in two contrasting functions, viz., sensing and intuition. The two judging functions are feeling and thinking. Jungian theory suggests that optimal human functioning draws on all four psychological functions: sensing (S), intuition (I), feeling $(\mathrm{F})$, and thinking $(\mathrm{T})$. The SIFT approach to biblical hermeneutics argues that rich engagement with the Word of God is enhanced by the engagement of all four psychological functions.

In terms of the perceiving functions, sensing types focus on the given evidence of the present situation as perceived by the senses. They tend to be concerned with specific details, rather than the overall picture. They are concerned with the actual, the real, and the practical. They tend to be down to earth and matter of fact. Intuitive types focus on the possibilities of the situation, perceiving meanings and relationships. They tend to concentrate on associations, intuitions and the wider themes that go well beyond the sense perceptions. They tend to focus on the bigger picture and on the future possibilities, rather than on specific facts and details.

In terms of the judging functions, feeling types form evaluations based on subjective personal and interpersonal values. They emphasise compassion and mercy. They are known for their tactfulness and for their desire for peace. They are more concerned with providing harmony than with adhering to abstract principles. Thinking types form evaluations based on objective, impersonal logic; they emphasise integrity and justice. They are known for their truthfulness and for their desire for fairness. They consider conforming to principles to be more important than cultivating harmony.

\section{Research question}

Against this background, the aim of the present study is to employ the SIFT approach to explore the interpretation of pericopes added by Matthew to Mark to amplify his understanding of Pilate and Judas. The two pericopes added within Matthew 27:19-25 (concerning Pilate) are rich in material to engage the perceiving functions (sensing and intuition). The pericope added within Matthew 27:3-10 (concerning Judas) is rich in material to engage the judging functions (thinking and feeling). The opportunity to structure workshops to explore these two passages of scripture within type-alike groups of experienced preachers was provided by a full-day programme convened by Waterloo Lutheran Seminary during the week before Holy Week 2017 as part of its commitment to the continuing professional development of clergy. The week before Holy Week was an ideal time for helping clergy to focus on the Passion Narrative.

\section{Method}

\section{Procedure}

Following an introduction to the theology of individual differences and to psychological type theory, participants were invited to complete a recognised measure of psychological type and to select their best fit on the four preferences between introversion and extraversion, between sensing and intuition, between thinking and feeling, and between judging and perceiving. They were then invited to participate in two hermeneutical communities. The first one was structured on the basis of the perceiving process and explored Matthew 27:19-25 through the lenses of sensing and intuition. The second was structured on the basis of the judging process and explored Matthew 27:3-10 through the lenses of thinking and feeling. Each of these communities was divided into four groups: in the first case, one group of high scoring sensing types, one group of high scoring intuitive types, and two groups of lower scoring types; in the second case, one group of high scoring thinking types, one group of high scoring feeling types, and two groups of lower scoring types. Each group was asked to nominate one of the members to document and to feed back to the plenary session.

\section{Measure}

Psychological type preferences were assessed by the Francis Psychological Type Scales (Francis 2005). This 40-item instrument comprises four sets of 10 forced-choice items related to each of the four components of psychological type theory: orientation (extraversion or introversion), perceiving process (sensing or intuition), judging process (thinking or feeling), and attitude towards the outer world (judging or perceiving). Recent studies have demonstrated that this instrument functions well in church-related contexts. For example, among a sample of 248 Anglican clergy and lay church officers Francis, Craig and Hall (2008) reported alpha coefficients of .83 for the EI scale, .76 for the SN scale, .73 for the TF scale, and .79 for the JP scale.

\section{Participants}

Of the 24 participants, there were 10 men and 14 women; 4 participants were in their twenties or thirties, 9 were in their forties or fifties, and 11 were in their sixties or seventies. In terms of the orientations, there were 6 extraverts and 18 introverts. In terms of the perceiving process, there were 7 sensing types and 17 intuitive types. In terms of the judging process, there were 9 thinking types and 15 feeling types. In terms of the attitude towards the outer world, there were 14 judging types and 10 perceiving types.

\section{Analysis}

One of the authors was present in the group of high scoring sensing types and then in the group of high scoring feeling types. The other author was present in the group of high scoring intuitive types and then in the group of high scoring thinking types. As non-participating observers they took detailed notes of the conversations. The results section of this article presents a summary and analysis of the notes taken in this context.

\section{Results: The perceiving process}

The perceiving process focused on Matthew 21:19-25, a passage that contains three main sections: the warning sent 
to Pilate by his wife to have nothing 'to do with that innocent man'; the shout of the people 'Let him be crucified'; and Pilate washing his hands before the people. The participants were asked to address the two following questions: What do you see in this passage? and what sparks your imagination in this passage?

\section{Sensing}

The group of six highest sensing types sat in silence and thought about the passage and about the task. It did not feel as if this was going to be an easy experience. When the first voice broke the silence it did so to raise a sensing-type question, 'I am trying to see the judgement seat on which Pilate sat. What does it look like? Does it look like a Bishop's chair?' No one had an answer to offer.

'What interests me', said the second voice, 'is what had led up to people saying what they did. Why did Pilate's wife so readily trust her dream?' We do not know enough about what is going on in the background. What is Pilate's wife doing there anyway? What role did she have in the government? Why should Pilate listen to her today? And why did Matthew decide to add this to Mark's story? Now these really were the detailed questions seeking important information. But unfortunately the evidence was just not there to address such sensing-type questions.

The first voice came back and suggested that the group should look at Pilate sitting on the judgement seat. Sitting there Pilate seemed to be acting as a sensing type concerned with very concrete questions: Which of the two do you want me to release to you? Then what should I do with Jesus? Why, what evil has he done? Here was someone examining the detailed text with care.

The third voice picked up this concern with Pilate. 'I want to know what kind of leader he was if he couldn't take a stand? Why is he not doing his job? Sitting on the judgement seat, it is his job to do what is right'.

The fourth voice, getting inside the narrative, noted that what crystallised Pilate's decision was how he saw that a riot was beginning. The answer is there in the text. He saw that he could do nothing to change the situation, so he is playing the situation so that he comes out well. I see someone sitting on the judgement seat who is not able to take a stand.

The fifth voice looked up from the text and spoke for the first time. 'What I hear in the passage are a lot of powerful and disturbing words: judgement, riot, crucify, blood'. Detailed sensing-type examination of the text was paying off.

Now the second voice came back and tried to turn attention away from Pilate onto Jesus. 'I just see Jesus standing there, saying and doing nothing. He is the one who really has the power, and he acts as someone who is completely powerless'. However, the group was not yet ready to pass on from Pilate. The sixth voice, who had so far been silent, burst into life:
'There is a curiosity in this passage that I had not noticed before. Pilate did something very practical. He took water and washed his hands. He said, I am innocent of this man's blood. He does not have blood on his hands.'

Then the first voice came back, determined to complete the story. The blood is on the people's hands and on their children's hands. These details are important.

Looking back at the task on which the group was supposed to be working, the second voice observed that he was struggling to see where imagination comes into the passage. The passage just seemed so strong and sinister. 'What I still want to know', said the second voice, 'is what is going on in Pilate's head when he is sitting there on the seat of judgement'.

One of the group then went back to the text to see if it could help answer that question. Listen, he said, to how Pilate speaks of Jesus, 'What should I do with Jesus who is called the Messiah?' Later on Pilate seems to have made up his mind when he nails to the cross the notice, 'Jesus the King of the Jews'. But here he does not seem so sure. We cannot really tell from the text what Pilate actually believed. The notice on the cross may have been a political game to annoy the Jewish leader.

Still looking at the details, one of the group suggested turning attention to the crowd. What does the passage say about them?

'They all seem to be speaking with one voice. They all call for Barabbas. They all shouted, Let him be crucified. They all said, His blood be on us and our children! Not many days earlier, they had all shouted, 'Hosanna to the Son of David'. It sounds as if everyone is of one voice and the others have been silenced.'

This conversation led to another close analysis of the text. Someone observed that we do not really know who the crowd are. Recalling the context as Passover reminded him that the city would be full of strangers. They would not really know what was going on. They were not in a position to form an independent judgement. They would literally follow the crowd.

Then suddenly time seemed to have run out. The group of sensing types had given a lot of attention to the details of the text and to the context that had shaped the text. There remained a lot of the back story that they longed to know but just could not discover. Clearly time had been too short for this group to exhaust the sensing question, 'What do you see in this passage?', and until they could exhaust the question, there seemed little point in trying to move on to explore the intuitive question, 'What sparks your imagination in this passage?'

\section{Intuition}

The group of seven highest scoring intuitive types lost no time in sharing what had sparked their imagination in 
the passage. The first voice broke in immediately and with passionate conviction. For him the passage had sparked a profound sense of unfairness. For him Pilate was nothing less than a monster. He said that the passage 'bothers me, upsets me. It is wrong. I have to challenge every aspect of it'. This profound sense of unfairness sparked two other thoughts. He recalled how Pilate got demoted by his imperial superiors. He recalled how the Jews got the blame. The passage had sparked his imagination.

The second voice came in as soon as there was a pause. Here imagination had been sparked, not by Pilate, but by Pilate's wife: 'Pilate's wife's empathy struck out at me'. The third voice, another woman, moved quickly to the image of Pilate washing his hands of the blood. For her the linkage with the Shakespearean Lady Macbeth was all too powerful. 'I kept thinking of Lady Macbeth', she said.

The fourth voice, again a woman, went back to the way in which the blame was placed on the Jews and how the passage had been a springboard for anti-Semitism. She then began to draw links with the powerful salvific imagery of blood. She drew links with how the blood of the Passover lamb is a symbol of God's saving act through the Exodus, and how the blood of Jesus is a symbol of God's saving act through Jesus. Then she drew a further link from the imagery of blood. For her there was irony in how God's salvific act could be used to fan anti-Semitism. The first voice came back, committed to exonerating the Jews from responsibility. 'The Romans crucified Jesus and that decision was made by Pilate'.

This interplay caused the fourth voice to take a closer look at Pilate, and this time through the lens of power. Here themes of power, victimhood, and salvation are being played out. 'Pilate is the person in power, but he plays the role of the victim. So often this happens in life, personally and systemically'. The fifth voice reinforced this point: 'I'm curious about Pilate's claim to victimhood, and how that plays out against his actual status?'.

This discussion of power sparked other ideas about powerlessness. The first voice came back with his concern for the powerlessness of the Jewish people in the face of antiSemitism: 'Jews have suffered for thousands of years'. A female voice then entered the conversation, linking the discussion to the powerlessness and marginalisation of women.

This reflection on the powerlessness of women brought another male voice into play speaking now for the first time. He was keen to bring reflection back to Pilate's wife who appears neither powerless nor marginalised in the narrative. Divergent views quickly emerged about the grounds for her intervention and the kind of knowledge she brought to her intervention. One participant felt that true information had been disclosed to Pilate's wife about Jesus' innocence directly by God in a dream. Another queried Pilate's wife's depth of concern for Jesus. Surely she was trying to deflect her husband from getting caught up in this religious and political controversy.
The mention of Jesus' innocence took the conversation off in yet another direction. One of the male voices interjected forcefully, 'Jesus is the true innocent. It is all about reversal'. The idea of reversal stimulated further contrasts to be set side-by-side. Jesus who is wholly innocent is being charged as a criminal deserving death. The Roman occupiers who appear to have the power are being controlled by the local religious leaders. The Romans who exercise the power of the death sentence pass the responsibility onto the Jews.

This debate about the balance of power between the occupying governor and the local people raised a conversation about power in democracies, and sparked reflections on the political situation in the UK (Brexit) and in the US (President Trump). Both were outcomes of democratic processes, and both were influenced by the crowd absorbing information and misinformation.

Now a reflective voice redirected attention back to the crowd in the narrative who cried 'Crucify', and invited all the participants to reflect on 'How we are part of the crowd that gets whipped up?' The male voice that had been the first to speak came back into play with force and enthusiasm: 'All of them condemned Jesus, and no one within the crowd steps up to take responsibility. It is like a bus rolling down a hill to an inevitable and unstoppable crash'.

When the group was asked to sum up the discussion, it recapped that the passage had sparked their imagination about a number of themes, including:

- passing the blame and scapegoating

- the roots of anti-Semitism

- a group being influenced to make a poorly informed choice

- the tension between fear and power

- not being too quick to judge any of the characters.

From this summary, it is clear that this group of intuitive types really had jumped ahead and passionately responded to the second question, 'What sparks your imagination in this passage?' They closed their session and returned to the plenary gathering without recognising that they had completely overlooked the first question, 'What do you see in this passage?'.

\section{Results: The judging process}

The judging process focused on Matthew 27:3-10, a passage that contains the remorse and suicide of Judas and the response of the chief priests in purchasing the Field of Blood. The participants were asked to address the following two questions: What issues in this passage touch your hearts? and what issues in this passage stretch your mind?

\section{Feeling}

The group of the six strongest feeling types sat round the table and looked at each other. The atmosphere was heavy. The first voice broke the silence with a question: 'Is anyone 
else bothered by the disconnection between suicide and repentance?'

No one answered this question. It just landed heavily in the room. Then the second voice chipped in:

'What touches my heart is Judas. Judas was offered the money. He had done what he was paid to do. But those who paid him just don't want to know. He comes back to them and they push him away. He has blood on his hands and he has to carry that burden alone. It has all fallen on his head.'

The third voice picked up the theme:

'My heart is heavy for Judas because he did repent, but he did not experience forgiveness. Things were different for Peter. In a different way he too betrayed Jesus. Peter went outside and wept bitterly. But Peter did know forgiveness. Jesus took him back and he felt forgiven.'

Then the fourth voice put himself into the story: When Judas came back to them they responded so coldly, so much without feeling, 'What is that to us. See to that yourself'. Judas was alone. Judas was screwed. Judas is trying to give the money back but they would not take it.

Then the second voice returned to the conversation and noted how the money was used - to buy a place to bury strangers, to bury foreigners. It was a place for outcasts. Knowledge of that must have placed added pressure on Judas. He too felt like an outcast and killed himself. But he could not even be buried in the field set aside for foreigners.

Then the group's heart went out to the potter who sold the field. The 30 pieces of silver were blood money. Judas did not want the money to stick to his hands. He threw the coins on the floor of the temple. The chief priests picked them up, but they did not want to keep them. They did not want the money to stick to their hands. So what about the potter? Did the potter know that he had sold his field for blood money? What may have befallen him as a consequence? The first voice broke into the conversation again at this point, noting that it is like reading Shakespeare. Everyone is dead at the end.

In a vain attempt to lighten the mood, the fifth voice (who had been silent up to this point) suggested that it was not all bad. The purchase of the field had at last provided somewhere in Jerusalem for Gentiles to be buried. Gentiles were being accepted at last, even if only in death.

At this point the group noticed the second task assigned to the workshop. The first voice that had started the initial conversation on the first task was once again the first to speak. 'What stretches my mind', he observed, 'is what is up with Judas now? It stretches my mind because there is a million answers to that question'. Hearing that question, this speaker's heart clearly went out to Judas: he did not see that there was much room in Christian theology to place Judas outside God's grace. Jesus died for Judas as much as for everyone else. Then Jesus, who prayed for forgiveness for those who hammered the nails into his hand, must surely have prayed for Judas too. Not all the group, however, were quite so comfortable with a gospel of universal salvation and pointed out that many good Christians would reject that view.

The question 'What is up with Judas now?' then prompted a new conversation about the Church's attitude towards suicide, and the pastoral response of clergy to the friends and family of those who have committed suicide, as well as the extension of the issue to that of assisted dying. One member of this group of feeling types said he struggles with the whole issue of suicide. Then other members of the feeling group related accounts of how they had encountered suicide within their pastoral ministry and, in one case, within close family. One of them related the concern of a mother: Does God still like my son? That is a real question, that is, with real pain. Then the heart of the group went out to people who are driven to commit suicide. People have real reasons for doing so. Life is so bleak for them.

At that point concern moved away from Judas to the other disciples. What, someone wondered, would the other 11 have made of Judas' suicide? After all Judas has been there with them through so much. Judas had even been there at the last supper. They had already lost Jesus. Now one of their number was dead. What was their future going to look like?

Time had run out and this group of feeling types was feeling exhausted by the process, exhausted and wrung out. They had engaged with a lot of feeling judgement, but very little with analytic judgement.

\section{Thinking}

The group of seven highest thinking types was keen to find a framework through which to start the conversation. The first voice to speak exemplified extraverted thinking's concern for planning. She noted that the events of the previous week had not turned out for Judas as he had planned. 'Things did not go the way Judas thought that they would'. Considering the archetypal scale of Christ's passion and the dramatic discussion of the blood money, rejection, and suicide, this opening observation emerged as a cool reflective analysis of why things turned out as they did. They were an inevitable consequence of things not going to plan.

The second voice picked up and developed what was only implicit in the opening observation. Here was an analysis to get to the roots of Judas' motivation: 'Judas was trying to push Jesus into a corner, so that he would be forced to make a Zealot-like military response'. When that failed, things had gone disastrously wrong with Judas' plan: 'Jesus did not line up to Judas' expectations'.

The next puzzle to solve concerned Judas' dialogue with the chief priests and elders. Judas emerged as an honest man who wanted to put the record straight. He had betrayed 
innocent blood. The hard thing is that Judas' confession was not received by the religious elite. He was not listened to. He could not put right his mistake, and he could not live with that realisation.

The group then tested a range of other ideas that may help to illuminate Judas' motivation and responsibility. One participant drew on the implications of substitutionary expiation atonement theory (as he called it) to provide a wider theoretical background. 'Someone had to do it', that is betray the Son of God. So perhaps Judas had no real choice in the matter?

Another participant explored the part that the 30 pieces of silver had to play in Judas' motivation. 'Was Judas hung up on the money? The rest of the disciples trusted Judas enough to trust him with their money'. After all Judas held the common purse. So how important was the financial incentive to him of that payment of 30 pieces of silver? A third perspective, however, argued that the 30 pieces of silver were really a distraction from the big issue. There was no getting away from the enormity of what Judas actually did.

Still thinking about the 30 pieces of silver, the group turned attention to the use to which the religious leaders put this money. Why did they use it to buy the field as a place to bury foreigners? Did they do this 'to justify themselves by looking good?'. Yet the religious leaders did not care about Judas; so why should they care about foreigners?

Reflecting further on this use of the 30 pieces of silver, one of the participants pressed the inconsistency of the passage. On the one hand, the money could not be put into the treasury. Yet, on the other hand, the money could be used to buy the Potter's field. What is the subtle difference between these two uses of money? Just what were the rules that were at play in shaping this decision?

Another point worth further scrutiny concerned the ownership of the field. 'Did the Potter's field really belong to a potter? And what is the significance of that point?'.

Pressed for a wider application of the narrative in the life of the Church today, one participant returned to the 30 pieces of silver and suggested that this raises questions about how religious leaders use their resources today. In the narrative the leaders first used the money to trap Jesus and to get rid of someone whom they found inconvenient. Then they used some of the money to solve a local problem concerned with disposing of the bodies of Gentiles who could not be buried in Jewish cemeteries. There is a lot to think about there.

Time had run out and this group of thinking types was still warming up to the passage and to their topics. There were issues still to explore and views to examine. They could have continued profitably for a much longer period dealing with the question, 'What issues in this passage stretch your mind?', before even recognising that there was a second question awaiting their attention, 'What issues in this passage touch your heart?'.

\section{Discussion}

This study set out to employ the SIFT approach to biblical hermeneutics to explore the interpretation of pericope added by Matthew to the Marcan passion narrative to amplify his understanding of Pilate and Judas. The pericope added within Matthew 27:19-25 concerning Pilate was discussed by groups differentiating between sensing types and intuitive types because these materials were rich in content to engage the perceiving process. The pericope added within Matthew 27:3-10 concerning Judas was discussed by groups differentiating between feeling types and thinking types because these materials were rich in content to engage the judging process. The distinctive voices of these four perspectives (sensing, intuition, feeling, and thinking) have emerged clearly in the foregoing presentation of the results. In this section the aim is twofold: to dialogue these new findings with the wider discussion of psychological type theory; and to dialogue these new findings with the wider body of research emerging from the empirical investigation of the SIFT approach to other biblical narratives. The dialogue will draw especially on three recent SIFT-related studies: the Lukan post-resurrection encounter with Jesus on the road to Emmaus (Lk 24:13-35) reported by Francis and ap Siôn (2016a); the Marcan narrative of conflict involving the clearing of the Temple and the incident of the fig tree (Mk 11:11-21) reported by Francis and ap Siôn (2016b); and the Lukan miraculous catch of fish and call of the first disciples (Lk 5:17) reported by Francis and ap Siôn (2017).

\section{Sensing}

Jung in the definitions section of his treatise Psychological Types writes that sensing is 'the psychological function that mediates the perception of a physical stimulus' (1971:461). Myers (1980:57) describes the implication of this for those having a sensing preference: 'Whatever comes directly from the senses is part of the sensing types' own experience and is, therefore, trustworthy'. Hunziker (2016:132) says 'sensing means that we mostly notice concrete facts'. Features of the discussion by the six highest scoring sensing types of Matthew's account of Pilate's encounters with his wife, with the religious authorities, with the crowd, and with Jesus support what would be predicted from these Jungian formulations of the sensing function. Furthermore, these features correspond to those reported in discussions in similarly designed studies of other biblical episodes involving sensing types in a variety of Christian groups.

In the present study concern for detail pervades the sensing types' 30-min discussion. For example, at the outset curiosity is expressed about how Pilate's judgment seat might resemble a bishop's chair. Similarly in the study of the Lucan call of the first disciples and the miraculous catch of fish reported by Francis and ap Siôn (2017), the group of sensing types wanted to know whether the great shoal of fish may have been seen 
better by Jesus on the shore than by the fishermen in the boat. In the present study general hunger was displayed for more details than the text itself provided, such as 'Why did Pilate's wife so readily trust her dream'. This complements the overwhelm sensing types expressed in the study of the Lucan Road to Emmaus narrative because of the wealth of detail in Jesus' post-resurrection encounter with friends walking back from Jerusalem to the village of Emmaus (Francis \& ap Siôn 2016a). Concern is with detail, too much or too little. In both studies the sensing types wanted to resolve ambiguity, 'How could the friends not recognise their esteemed teacher!' in the Emmaus narrative, while in the present study resolving whose hands were bloodied was important. Often group members went to the text to resolve the question, in contrast to the group of intuitive types where one speculation was floated after another with no pressure felt to resolve the issues raised either through reasoning or checking the text.

The group discussion provided evidence for sensing types being drawn to the practical: 'Pilate did something very practical. He took water and washed his hands'. An intuitive type, if drawn to Pilate's action, might characterise it as symbolic and attention gravitate towards it for that reason. Furthermore, whether the person featured in the narrative was personally agreeable or not, readers of a particular type may prefer to recognise someone they can understand by attributing a shared preference. Thus Pilate's protest to the death-demanding crowd, 'What evil has he done?' is construed in this sensing group as a specifying question, such as a governor who was a sensing type might ask.

\section{Intuition}

Jung (1971:453) describes intuition as the function that mediates perceptions in an unconscious way', and argues that 'everything, whether outer or inner objects or their relationships, can be the focus of this perception'. The power of this unconscious element at work helps explain the abrupt shifts of focus and discontinuous content observed in the group of intuitive types. From the outset a voice broke in bewailing the total unfairness of the death sentence that unfolded. Voice two sounded immediately, but focused on Pilate's wife's empathy for Jesus. Voice three visited the hand-washing, while voice four secured this episode as the source-point of anti-Semitism. Here in $5 \mathrm{~min}$, there are four voices and four topics.

The jumping nature of the opening discussion resembles certain features of the process and the content of reported previous studies of groups of intuitive types discussing gospel stories. Francis and ap Siôn (2017) report:

After the reflective start, the pace of responses had really begun to pick up significantly. People entered the conversation more quickly and were sparking one another off, either by adding new insights or developing connections that others had made. This became particularly lively and engaged at its peak. (p. 193)

The same jumping-around was observed in this earlier study, but since it occurs in the middle of the discussion the observer is able to ascertain some thread of at least an intuitive connection undergirding the vocalised thoughts. These patterns validate Jung's claim that intuition is unconscious.

One of the ways that unconscious patterns of intuition are observed is through the emergence of themes that thread in and out of conversations between intuitive types. Sometimes themes manifest once in the discussion but are passionately claimed by participants as themes detected by intuition from elements in the biblical narrative. Thus, according to the second woman who spoke in our study, the theme of salvific blood played out first in the Exodus of the Hebrew people from Egypt, but then again in the meaning assigned to Jesus' death by crucifixion within the group. Similarly, Francis and ap Siôn (2016b) in reporting intuitive types discussing Jesus cursing the fig tree states, "The intuitive group opened the conversation immediately by announcing a large theme dominating the passage: "I see a very, very angry man"' (p. 4).

At other times in the group process intuitive themes emerge over a sustained 30-min discussion as was possible in the setting of the present study. The form often taken is: topic announced with passion, not taken up and seemingly ignored, and then returned to, sometimes little later, but often a lot later. When the group is comprised of intuitive types there seems an acceptance of this unconscious process of unspoken continuity in which a topic may eventually re-emerge and re-constitute as a theme. In this particular group there was the theme of unfairness that graced the beginning and returned in the last $5 \mathrm{~min}$ of the discussion. Salvation also quickly became another theme, but was then apparently supplanted by power.

When intuition is the prevailing function in an exchange, there can occur a grouping together of themes that in itself may become a fresh theme in its own right. The fourth person to speak does just that: 'Here themes of power, victimhood, and salvation are being played out. "Pilate is in power, but plays the role of the victim"'. Tellingly this grouping of themes is effected by a speaker who is in a significant position of power within the seminary. The surface discontinuities of vocalised comments are unconsciously linked through the natural process of intuitive perceiving.

\section{Feeling}

For Jung (1971:434) the feeling function was 'primarily a process that takes place between the ego and a given content ... and [one] that imparts to the content a definite value'. Myers (1980:66) saw the feeling function when well developed as 'a stable instrument for discriminating the worth of personal values ... which serves as the bridge between one human being and another'. Hunziker (2016:132) draws out the social implication when feeling predominates in a group: 'feeling ... employs $e$-valuation [with] anticipation of the impact ... choosing actions that will produce the most desirable, harmonious outcomes'. It came as no surprise then that the group of feeling types displayed a concern for the 
personal and interpersonal threads throughout that group's 30-min discussion of Judas' final hours. Resonance to disconnection suffused the entire time together. The mood was set at the beginning, and stayed, by the beseeching question 'Is anybody else bothered by the disconnection between suicide and repentance'. The question is never answered directly in terms of content, but rather affectively through a consistent outpouring of compassion for the myriad of ways that suffering is scattered in the text either explicitly or implicitly. There was a searching out for those whose suffering might be unacknowledged, for example the potter who may not have known the history of the coins given to him for the sale of his field. Group members' compassion extended to the present day including the challenge of encountering suicide in the ministry of individual pastors. The raising of wider issues occurred in both the thinking and feeling groups due probably to the presence of intuitive types in both, but there was a personally engaged emotional tone to the extrapolations beyond text when this happened among the feeling types.

'Effort to understand' was a further continuing feature in the discussion of Judas and replicated a preoccupation of previous groups of feeling types' shared exegesis as reported by Francis and ap Siôn (2016b) in their report of the commentary on Jesus' seeming intemperate cursing of the fig tree: in this context 'efforts were made to understand Jesus' emotional state' (p. 7).

Whereas the thinking function cognises and mediates formal conceptual relationships that may endure over time, feeling congregates personal values in a human moment, making for intensity rather than extensity. Intensity also featured in the group of thinking types, but there was evidence among the feeling types of both a willingness and a seeming comfort in directly owning the emotions evoked in the group, as evidenced, for example, by the claim, 'My heart is heavy for Judas because he did repent, but did not experience forgiveness'. There appeared also a readiness to confront negative feeling (or the absence of feeling) directly, as when the fourth person to speak quoted the religious leader's response to Judas returning the money given to him, 'What is that to us?'.

\section{Thinking}

Jung (1971:481) states: 'Thinking is the psychological function which, following its own laws, brings the contents of ideation into conceptual connection with one another'. Myers (1980:65) says of thinking: 'Thinking is essentially impersonal. Its goal is objective truth, independent of the personality and wishes of the thinker or anyone else'. For Hunziker (2016:132) thinking is a way of deciding that 'employs logical analysis ... based on cause effect analysis'. The emphasis on analysis featured several times in the thinking types' discussion of the last day of Judas' life.

Analysis took a variety of forms in the present study as had been observed in previous studies. Analysis was sometimes undertaken in order to decipher what seemed puzzling, as with the withered fig tree (Francis \& ap Siôn 2016b), at other times linking scripture to revelation in the thinking types' discussion of the Emmaus narrative (Francis \& ap Siôn 2016a). The first comment by thinking types in the present study concerned planning (identified by Jungian analyst and type theorist John Beebe (2017) as the quintessence of extraverted thinking): '[T]he previous week had not turned out as Judas had planned'. Planning involves the differentiation of an event as the result of a mental intention that requires the separative effect of the operation of the thinking function.

Another possibility that cause-effect analysis opens up is inquiry into motivation, albeit a less visible causal sequence. This is the search for the underlying motive, beloved of criminal lawyers and psychoanalysts alike, but also relevant to religious narratives. Accordingly, the second thinking voice avers that 'Judas was trying to push Jesus into a corner'. It goes without saying that, from a social scientific perspective, any human action has multiple causes, but will have even more conjectured causes when our thinking function is engaged. The long central section of the group of thinking types' discussion of Judas' final hours involve an examination of the financial aspect of the cause of Jesus' betrayal. However, once differentiated as a cause for one event, that cause can pivot and become an object of inquiry for ways in which that specific cause may exert wider influence in other areas. In this instance, the group extended their discussion of the use to which the religious leaders in the Matthean narrative put their 30 pieces of silver, and the extension led to an excursus regarding good stewardship of the Church's and the Earth's resources.

The differentiation of cause and effect seems at the heart of the difference between the ways in which thinking-judging types and feeling-judging types discuss the same narrative. This makes for a different tone in the presentation of the two groups. The thinking approach offers a cool analysis, while, in contrast, the feeling approach overlays a set of pertinent values. This 'value-overlay' takes place in a single moment that makes for a concentrated intensity. In the report back to the workshop as whole, the account made by the group of feeling types had an intensity that the report by the group of thinking types lacked. By the same token, the report by the group of thinking types had a range of content and issues that did not feature in the account made by the group of feeling types.

\section{Conclusion}

Two main conclusions can be drawn from the present study, one focused specifically on the Matthean pericopes added to the Marcan passion narrative that address psychological questions raised by the psychological motivation and the psychological consequences for two key protagonists in the arrest, trial, and crucifixion of Jesus (Pilate and Judas), and the other focused more broadly on the SIFT approach to biblical hermeneutics. 
In respect of Pilate and Judas, the present study has confirmed the richness of the Matthean pericopes for exploring specific aspects of the psychological and theological puzzles posed by the starker account afforded by the earlier Marcan passion narrative. When readers are invited to reflect on these pericopes in a systematic and disciplined way within a group context, these pericopes bear considerable weight in enriching the Christian community's engagement with and participation in the scripturally grounded and liturgically shaped journey of Holy Week through to Good Friday. The workshops described in this article and experienced within the Waterloo Lutheran Seminary are worth replicating elsewhere.

In respect of the SIFT approach to biblical hermeneutics, rooted within the reader-perspective approach, the present study has added one more piece to the developing tapestry documented by the 18 earlier studies listed in the introduction to this article. The SIFT approach argues that a fuller and richer engagement emerges within the conversation between the Word of God and the People of God when the People of God take time to explore the Word of God as a community activity and when the community is fully conscious of the implications of psychological type theory for uncovering and for bringing into consciousness multiple layers of meaning. This series of studies not only documents a scientific endeavour, but also introduced a purposive and fruitful approach for engaging more deeply with scripture within local churches, within local study groups, and within professional development programmes for authorised (lay and ordained) ministers. The application, implementation, and interpretation of the SIFT approach does, however, assume serous engagement with the insights and critique of psychological type theory.

\section{Acknowledgements Competing interests}

The authors declare that they have no financial or personal relationships which may have inappropriately influenced them in writing this article.

\section{Authors' contributions}

L.J.F. designed and structured the research programme and led on the introduction. Both authors collaborated on the results and conclusion. C.F.R. led on the discussion.

\section{References}

Barclay, W., 1957, Gospel of Matthew: Volume 2, St Andrew's Press, Edinburgh.

Bassett, R.L., Mathewson, K. \& Gailitis, A., 1993, 'Recognising the person in biblical interpretation: An empirical study', Journal of Psychology and Christianity 12, 38-46.

Beebe, J., 2017, Energies and patterns in psychological type: The reservoir of consciousness, Routledge, New York.

Bleich, D., 1978, Subjective criticism, The Johns Hopkins University Press, Baltimore, MD.

Bond, H.K., 1998, Pontius Pilate in history and interpretation, Cambridge University Press, Cambridge. https://doi.org/10.1017/СB09780511585166

Booth, W.C., 1984, The rhetoric of fiction, University of Chicago Press, Chicago, IL.

Boring, M.E., 1994, Matthew: The new interpreter's Bible, vol. 8, Abingdon Press, Nashville, TN.
Brown, R.E., 1994, The death of the Messiah, Doubleday, New York.

Callon, C., 2006, 'Pilate the villain: An alternative reading of Matthew's portrayal of Pilate', Biblical Theological Bulletin 36, 62-71. https://doi.org/10.1177/01461079 060360020301

Chaim, W., 2013, 'Typy psychologiczne w recepcji i przekazie slowa bożego [Psychological typology in the reception and transmission of the Word of God]', Roczniki Pastoralno-Katechetyczne 5, 155-170.

Chaim, W., 2014, 'Metoda interpretacji i przepowiadania slowa bożego SIFT w slużbie kaznodziejstwa cala dusza [The SIFT method in the service of preaching with al our souls]', Roczniki Teologiczne 61, 117-136.

Chaim, W., 2015, 'Profil typu psychologicznego, interpretacja biblii I głoszenie słowa bożego (badania empiryczne) [Psychological type profile, biblical hermeneutics and liturgical preaching (empirical research)]', Resovia Sacra 22, 45-69.

Ellens, J.H., 2012, 'Psychology and biblical studies: Birth and development of a new SBL program unit (1991-2011)', in J.H. Ellens (ed.), Psychological hermeneutics for biblical themes and texts: A festschrift in honour of Wayne G. Rollins, pp. 21-42, biblical themes and

Ellens, J.H. \& Rollins, W.G. (eds.), 2004, Psychology and the bible: A new way to read the scriptures (Vol. 3: From Gospel to gnostics), Praeger, Westport, CT.

Fish, S., 1980, Is there a text in this class? Harvard University Press, Cambridge, MA.

France, R.T., 2007, The Gospel of Matthew, William B. Erdamans, Grand Rapids, MI.

Francis, L.J., 1997, Personality type and scripture: Exploring Mark's Gospel, Mowbray, London.

Francis, L.J., 2005, Faith and psychology: Personality, religion and the individual, Darton, Longman and Todd, London.

Francis, L.J., 2010, 'Five loaves and two fishes: An empirical study in psychological type and biblical hermeneutics among Anglican preachers', HTS Theological Studies 66(1), Article \#811, 1-5. https://doi.org/10.4102/hts.v66i1.811

Francis, L.J., 2012a, 'What happened to the fig tree? An empirical study in psychological type and biblical hermeneutics', Mental Health, Religion and Culture 15, 873-891. https://doi.org/10.1080/13674676.2012.676252

Francis, L.J., 2012b, 'Interpreting and responding to the Johannine feeding narrative: An empirical study in the SIFT hermeneutical method among Anglican ministry training candidates', HTS Theological Studies 68(1), Article \#1205, 1-9.

Francis, L.J., 2013, 'Ordinary readers and reader perspective on sacred texts: Drawing on empirical theology and Jungian psychology', in J. Astley \& L.J. Francis (eds.), Exploring ordinary theology: Dimensions of everyday Christian existence and the life of the church, pp. 87-96, Ashgate, Farnham.

Francis, L.J., 2015, 'Footwashing and diaconal ordination', in J. Vincent (eds.), The Farewell discourses in practice, pp. 21-28, Deo Publishing, Blandford Forum.

Francis, L.J. \& ap Siôn, T., 2016a, 'Empirical theology and biblical hermeneutics: Exploring lessons for discipleship from the road to Emmaus (Luke 24:13-35)' Journal of Empirical Theology 29, 24-44. http://doi.org/10.1163/1570925612341000

Francis, L.J. \& ap Siôn, T., 2016b, 'Jesus, psychological type and conflict: A study in biblical hermeneutics applying the reader perspective and SIFT approach to Mark 11:11-21', HTS Theological Studies 72(4), 1-9. https://doi.org/10.4102/hts. v72i 4.3573

Francis, L.J. \& ap Siôn, T., 2017, 'Reading the Lucan call of the first disciples differently: The voices of sensing and intuition', Journal of Beliefs and Values 38, 188-198. https://doi.org/10.1080/13617672.2017.1291254

Francis, L.J. \& Atkins, P., 2000, Exploring Luke's Gospel: A guide to the gospel readings in the Revised Common Lectionary, Mowbray, London.

Francis, L.J. \& Atkins, P., 2001, Exploring Matthew's Gospel: A guide to the gospel readings in the Revised Common Lectionary, Mowbray, London.

Francis, L.J. \& Atkins, P., 2002, Exploring Mark's Gospel: An aid for readers and preachers using year $B$ of the Revised Common Lectionary, Continuum, London.

Francis, L.J., Craig, C.L. \& Hall, G., 2008, 'Psychological type and attitude toward Celtic Christianity among committed churchgoers in the United Kingdom: An empirical study', Journal of Contemporary Religion 23, 181-191. https://doi.org/10.1080/ 13537900802024543

Francis, L.J. \& Jones, S.H., 2011, 'Reading and proclaiming the resurrection: An empirical study in psychological type theory among ministry training and experienced preachers employing Mark 16 and Matthew 28', Journal of Empirical Theology 24, 1-18. https://doi.org/10.1163/157092511X571141

Francis, L.J. \& Jones, S.H., 2014, 'Life in the eucharistic community: An empirical study in psychological type theory and biblical hermeneutics reading John 6:5-15" Pastoral Psychology 63, 281-290. https://doi.org/10.1007/s11089-013-0540-x

Francis, L.J. \& Jones, S.H., 2015a, 'An empirical approach to Mark's account of discipleship: Conversation between the Word of God and the People of God', Rural Theology 13, 69-81. https://doi.org/10.1179/1470499415Z.00000000042

Francis, L.J. \& Jones, S.H., 2015b, 'Preparing for disability awareness Sunday: An educational exercise drawing on psychological perspectives for biblical hermeneutics', International Journal of Christianity and Education 19, 197-214. https://doi.org/10.1177/2056997115602485

Francis, L.J. \& Smith, G., 2012, 'Separating sheep from goats: Using psychological type theory in a preaching workshop on Matthew 25:31-46', Journal of Adult Theological Education 9, 175-191. https://doi.org/10.1179/ate.9.2.gw215220 35374468

Francis, L.J. \& Smith, G., 2013, 'Reading and proclaiming the birth narratives from Luke and Matthew: A study in empirical theology among curates and their training incumbents employing the SIFT method', HTS Theological Studies 69(1), Article 2001, 1-13. https://doi.org/10.4102/hts.v69i1.2001 
Francis, L.J. \& Smith, G., 2014, 'Reading and proclaiming the advent call of John the Baptist: An empirical enquiry employing the SIFT method', HTS Theological Studies 70(1), Article 2718, 1-9. https://doi.org/10.4102/hts.v70i1.2718

Francis, L.J. \& Smith, G., 2017, 'Learning relationships: Church of England curates and training incumbents applying the SIFT approach to the road to Emmaus', HTS Theological Studies 73(4), Article 4546. https://doi.org/10.4102/hts.v73i4.4546

Francis, L.J., Smith, G. \& Francis-Dehqani, G., 2017, 'The missionary journey of Mark 6 and the experience of ministry in today's world: An empirical study in biblical hermeneutics among Anglican clergy', HTS Theological Studies 73(3), Article 4560. https://doi.org/10.4102/hts.v73i3.4560

Francis, L.J. \& Village, A., 2008, Preaching with all our souls, Continuum, London.

Gubar, S., 2009, Judas: A biography, W. W. Norton and Company, New York.

Hunziker, M., 2016, Depth psychology: The guide map to becoming who we are, Write Way Publishing, Clayton, NC.

Jung, C.G., 1971, Psychological types: The collected works, vol. 6, Routledge and Kegan Paul, London.

Keirsey, D. \& Bates, M., 1978, Please understand me, Prometheus Nemesis, Del Mar, CA.

Kille, D.A., 2001, Psychological biblical criticism, Fortress Press, Minneapolis, MN. Klassen, W., 1996, Judas: Betrayer or friend of Jesus? SCM Press, London.

Myers, I.B., 1980, Gifts differing, Consulting Psychologists Press, Sunnyvale, CA.
Myers, I.B. \& McCaulley, M.H., 1985, Manual: A guide to the development and use of the Myers-Briggs Type Indicator, Consulting Psychologists Press, Palo Alto, CA.

Rollins, W.G., 1999, Soul and psyche: The Bible in psychological perspective, Fortress Press, Minneapolis, MN.

Rollins, W.G. \& Kille, D.A., 2007, Psychological insight into the bible: Texts and readings, Eerdmans, Grand Rapids, MI.

Segovia, F.F. \& Tolbert, M.A. (eds.), 1995b, Readings from this place: Social location and biblical interpretation in global perspective, Fortress Press, Minneapolis, MN.

Segovia, F.F. \& Tolbert, M.A. (eds.), 1995a, Reading from this place: Social location and biblical interpretation in the United States, Fortress Press, Minneapolis, MN.

Smith, G. \& Francis, L.J., 2016, 'Difficult texts: Mark 10:46-52', Theology 119, 200-203. https://doi.org/10.1177/0040571X15623706

Stiefel, R.E., 1992, 'Preaching to all the people: The use of Jungian typology and the Myers-Briggs Type Indicator in the teaching of preaching and in the preparation of sermons', Anglican Theological Review 72, 175-202.

Uraguchi, B., 1918, 'The psychology of Judas Iscariot', The Biblical World 51, 345-360. https://doi.org/10.1086/476065

Village, A., under review, The Bible and psychology.

Wright, T., 2002, Matthew for everyone: Part 2, SPCK, London.

Wroe, A., 1999, Pilate: The biography of an invented man, Jonathan Cape, London. 


\section{Appendix 1 \\ Matthew 27:19-25}

While he was sitting on the judgement seat, his wife sent word to him, 'Have nothing to do with that innocent man, for today I have suffered a great deal because of a dream about him'.

Now the chief priests and the elders persuaded the crowds to ask for Barabbas and to have Jesus killed. The governor again said to them, 'Which of the two do you want me to release for you?' And they said, 'Barabbas'. Pilate said to them, 'Then what should I do with Jesus who is called the Messiah?' All of them said, 'Let him be crucified!' Then he asked, 'Why, what evil has he done?' But they shouted all the more, 'Let him be crucified!'

So when Pilate saw that he could do nothing, but rather that a riot was beginning, he took some water and washed his hands before the crowd, saying, 'I am innocent of this man's blood; see to it yourselves'. Then the people as a whole answered, 'His blood be on us and on our children!'

What do you see in this passage?

What sparks your imagination in this passage?

New Revised Standard Version (Anglicised Edition)

\section{Appendix 2}

Matthew 27:3-10

When Judas, his betrayer, saw that Jesus was condemned, he repented and brought back the 30 pieces of silver to the chief priests and the elders. He said, 'I have sinned by betraying innocent blood'. But they said, 'What is that to us? See to it yourself'. Throwing down the pieces of silver in the temple, he departed; and he went and hanged himself. But the chief priests, taking the pieces of silver, said, 'It is not lawful to put them into the treasury, since they are blood money'. After conferring together, they used them to buy the potter's field as a place to bury foreigners. For this reason that field has been called the Field of Blood to this day. Then was fulfilled what had been spoken through the prophet Jeremiah:

And they took the 30 pieces of silver, the price of the one on whom a price had been set, on whom some of the people of Israel had set a price, and they gave them for the potter's field, as the Lord commanded me.

What issues in this passage touch your heart? What issues in this passage stretch your mind?

New Revised Standard Version (Anglicised Edition) 